\title{
Hubungan Depresi, Ansietas, dan Stres dengan Kejadian Sindrom Dispepsia pada Mahasiswa Tahun Pertama di Fakultas Kedokteran Universitas Andalas Sebelum dan Sesudah Ujian Blok
}

Muhammad Husnul Ikhsan ${ }^{1}$, Arina Widya Murni², Erlina Rustam ${ }^{3}$

\begin{abstract}
Abstrak
Sindrom dispepsia merupakan keluhan gastrointestinal yang sangat umum di semua kalangan termasuk mahasiswa. Banyak penyebab yang memicu sindrom dispepsia, salah satunya adalah pengaruh psikologis khususnya depresi, ansietas, dan stres. Banyaknya ujian kompetensi yang dilalui mahasiswa kedokteran, sering menimbulkan masalah psikologis. Tujuan: Mengetahui hubungan depresi, ansietas, dan stres dengan kejadian sindrom dispepsia pada mahasiswa tahun pertama di Fakultas Kedokteran Universitas Andalas sebelum dan sesudah ujian blok. Metode: Penelitian ini merupakan penelitian analitik dengan one group pre dan post design. Subjek penelitian diperoleh dengan menggunakan metode simple random sampling dari populasi lima puluh mahasiswa tahun pertama. Penelitian menggunakan Kuesioner DASS 21 dan Kriteria Roma IV. Hasil: Insidensi yang paling tinggi adalah depresi ringan $(12,0 \%)$, ansietas sedang (34,0\%), dan stres ringan (28,0\%), serta sindrom dispepsia pada dua puluh tiga mahasiswa (46,0\%). Depresi dan ansietas mengalami peningkatan secara signifikan setelah ujian blok. Nilai signifikansi depresi 0,183, ansietas 0,046 dan stres 0,021. Simpulan: Ansietas dan stres berhubungan secara signifikan dengan kejadian sindrom dispepsia karena $\mathrm{p}<0,05$. Diharapkan adanya perhatian khusus oleh Bagian Pendidikan Kedokteran untuk kondisi biologis dan psikologis mahasiswa yang lebih baik.
\end{abstract}

Kata Kunci: depresi, ansietas, stres, sindrom dispepsia, mahasiswa

\begin{abstract}
Dyspepsia syndrome is a gastrointestinal complaint that is very common in all people including students. Many causes that trigger dyspepsia syndrome, like a psychological influence, especially depression, anxiety, and stress. Many competency exams passed by medical students often cause psychological problems. Objectives: To determined the relations of depression, anxiety, and stress on the event of dyspepsia syndrome on first year students of the Faculty of Medicine, Andalas University before and after multiple choice examination. Methods: This research was an analytic study with one group pre and post design. Research subjects were obtained using a simple random sampling method from a population of fifty of first year students. This research used Depression Anxiety Stress Scale (DAS 21 Questionnaire and Roma IV Criteria. Results: The highest incidence were mild depression (12.0\%), moderate anxiety (34.0\%), mild stress (28.0\%), and dyspepsia syndrome in twenty three of students (46.0\%). Depression and anxiety had increased significantly after multiple choice examination. The significance value of depression is 0.183 , anxiety is 0.046 and stress is 0.021. Conclusions: Anxiety and stress are significantly related to the event of dyspepsia syndrome because of $p<0.05$. Special attention is expected by Student Service Unit for better student's biological and psychological conditions.
\end{abstract}

Keywords: depression, anxiety, stress, dyspepsia syndrome, students 
Kedokteran, Universitas Andalas, Padang, Indonesia. 3. Bagian Farmakologi, Fakultas Kedokteran, Universitas Andalas, Padang, Indonesia

Korespondensi: Arina Widya Murni, Email: skripsiikhsan@gmail.com Telp: 082387426671

\section{PENDAHULUAN}

Dispepsia merupakan salah satu masalah kesehatan yang sering ditemui pada praktek seharihari. Diperkirakan hampir 30\% kasus yang dijumpai pada praktek umum dan $60 \%$ pada praktek gastroenterologi merupakan dispepsia. Prevalensi dari dispepsia bervariasi antara $7-45 \%{ }^{1}$

Prevalensi dispepsia di seluruh dunia cenderung memiliki angka kejadian yang tinggi. Dari data pustaka negara barat didapatkan angka prevalensinya berkisar $7-41 \%$, tapi hanya $10-20 \%$ yang mencari pertolongan medis dan sisanya mengobati diri sendiri dengan obat bebas yang beredar luas di pasaran. Diprakirakan angka insiden dispepsia sampai 10\%, di mana kasus baru yang datang pada pelayanan kesehatan lini pertama sebesar $5-7 \% .^{2}$

Mayoritas studi yang dilakukan di Eropa Utara dan Asia Tenggara, didapatkan heterogenitas yang signifikan secara statistik. Prevalensi terendah dispepsia terjadi pada penelitian di Amerika Tengah $(7,0 \%)$ dan tertinggi di Amerika Selatan $(37,7 \%){ }^{3}$

Data Profil Kesehatan Indonesia tahun 2010 menunjukkan dispepsia sudah menempati peringkat ke5 untuk kategori penyakit terbanyak pasien rawat inap di rumah sakit tahun 2010 dengan jumlah pasien 24.716 dengan angka kematian 166 orang dan CFR (case fatality rate) $0,67 \% .{ }^{4}$ Dispepsia menjadi permasalahan kesehatan yang cukup serius di Kota Padang karena menempati peringkat ke-3 paling banyak terjadi di tahun 2017 dengan dispepsia 17.879 kasus. $^{5}$

Pada penelitian di RSUP Dr. M. Djamil Padang, Sumatera Barat tahun 2011 dengan populasi sebanyak 63 data penderita sindrom dispepsia tingkat pendidikan akademik (50,0\%). ${ }^{6}$ Penelitian pada 120 mahasiswa Institut Pertanian Bogor telah menunjukkan bahwa tingkat stres berhubungan dengan munculnya dispepsia. ${ }^{7}$ Hasil penelitian di RSUP Dr. M. Djamil Padang menunjukkan dari 61 orang pasien dispepsia, terdapat 41 orang yang mengalami depresi dan menunjukkan hubungan yang tinggi antara tingkat depresi dengan kualitas hidup responden sindrom dispepsia. ${ }^{8}$

Penelitian di Arab Saudi tahun 2011 pada 892 mahasiswa kedokteran mendapatkan hasil tingkat stres ringan 158 orang $(20,4 \%)$, tingkat stres sedang 141 orang $(18,2 \%)$, tingkat stres berat sebanyak 195 orang $(25,2 \%)$ dan yang tidak mengalami stres yaitu sebanyak 281 orang $(38,3 \%)$. Prevalensi stres lebih tinggi selama tiga tahun awal studi. Tingkat stres juga secara signifikan akan menurun seiring meningkatnya tahun kuliah kecuali pada tahun terakhir kuliah. ${ }^{9}$

Pengalaman akademik seringkali selama menempuh pendidikan kedokteran yang penuh dengan perjuangan tersebut membuat mahasiswa rentan mengalami gangguan cemas. $^{10}$ Kondisi gangguan psikologis sering terjadi pada mahasiswa tahun pertama. Apalagi pada mahasiswa kedokteran yang memiliki jadwal kuliah yang padat dan lebih lama daripada mahasiswa jurusan lainnya. Ditambah dengan banyaknya ujian-ujian yang harus dilalui mahasiswa kedokteran setiap semesternya, ujian blok, ujian keterampilan klinik, dan ujian praktikum.

Penduduk provinsi Sumbar umur $\geq 15$ tahun menduduki peringkat 7 terbanyak yang mengalami depresi berdasarkan data riskesdas tahun 2019. Faktor depresi, ansietas dan stres dapat mempengaruhi fungsi saluran cerna dan mengakibatkan perubahan sekresi asam lambung, mempengaruhi motilitas dan vaskularisasi mukosa lambung serta menurunkan ambang rasa nyeri. Pasien dispepsia umumnya menderita ansietas, depresi dan neurotik lebih jelas dibandingkan orang normal. ${ }^{11}$

Pada suatu penelitian tentang perbedaan tingkat stres mahasiswa kedokteran tahun pertama dan tahun ketiga di Universitas Muhammadiyah Malang tahun 2011 mendapatkan kesimpulan bahwa mahasiswa kedokteran tahun pertama memiliki tingkat stres lebih tinggi dibandingkan tahun ketiga. ${ }^{12}$ Penelitian pada mahasiswa kedokteran di Universitas Lampung pada tahun 2014 terlihat bahwa tingkat stres pada mahasiswa tahun pertama lebih berat apabila dibandingkan dengan tingkat stres pada mahasiswa tahun kedua. ${ }^{13}$

Penelitian yang sudah dilakukan di Prodi Kedokteran, Fakultas Kedokteran, Universitas Sebelas Maret, sebagian besar mahasiswa menghadapi 
perasaan cemas dalam menghadapi Objective Structured Clinical Examination (OSCE). Banyak faktor yang menyebabkan perasaan cemas pada mahasiswa yang akan menghadapi OSCE. Faktor terbanyak dari diri mahasiswa sendiri yaitu kebiasaan mahasiswa yang selalu cemas ketika akan menghadapi ujian. Pada beberapa mahasiswa ada yang memiliki kecemasan karena tidak siap dengan materi atau topik yang akan dihadapi serta masalah keterbatasan waktu. ${ }^{14}$

Frekuensi tingkat stres mahasiswa $\mathrm{S} 1$ program studi pendidikan dokter Fakultas Kedokteran Universitas Andalas angkatan 2013 hingga 2015, ternyata diperoleh bahwa sebagian besar mahasiswa yang normal yaitu 119 (75,3\%), tingkat stres ringan yaitu 16 orang $(10,1 \%)$, stres sedang 16 orang $(10,1 \%)$, stres berat sebanyak 5 orang $(3,2 \%)$ dan stres sangat berat sebanyak 2 orang (1,3\%). Berdasarkan data-data di atas cukup banyak masalah depresi, ansietas, dan depresi mahasiswa kedokteran. ${ }^{15}$

Pada suatu hasil survei, hampir semua mahasiswa Fakultas Kedokteran Universitas Andalas yang tidak lulus dalam blok yang sedang mereka jalani diakibatkan karena tidak lulus ujian tulis. Hasil survei ini menarik untuk diteliti lebih dalam, karena ini dapat menimbulkan permasalahan pada mahasiswa berupa kecemasan karena penyebab tersering tidak lulus blok adalah tidak lulus dalam ujian tulis bila dibandingkan dengan ujian pratikum ataupun ujian keterampilan klinis. $^{16}$

Hasil pengamatan menunjukkan bahwa setiap belajar bersama persiapan ujian blok, banyak mahasiswa yang mengalami nyeri pada bagian epigastrium. Hal ini sering dialami ketika ujian blok sudah dekat. Belum ada penelitian yang membahas bagaimana hubungan stres, ansietas, dan depresi mahasiswa tahun pertama fakultas kedokteran sebelum dan sesudah ujian blok terhadap kejadian sindrom dispepsia.

\section{METODE}

Jenis penelitian ini adalah analitik dengan rancangan pre and post design yaitu subyek penelitian diobservasi sebanyak dua kali sebelum dan sesudah ujian Blok 1.1 serta variabel diukur langsung pada penelitian tersebut. Variabel independennya adalah depresi, ansietas, dan stres pada pada responden dan variabel dependennya adalah kejadian sindrom dispepsia. Penelitian telah dilakukan dari bulan April sampai November 2019 di Fakultas Kedokteran Universitas Andalas, Padang, Sumatera Barat.

Sampel penelitian yang dipilih adalah mahasiswa tahun pertama di Fakultas Kedokteran Universitas Andalas yaitu angkatan 2019 jurusan S1 Kedokteran yang memenuhi kriteria inklusi dan tidak memiliki kriteria eksklusi. Kriteria inklusi subjek: Mahasiswa Angkatan 2019 S1 Kedokteran Fakultas Kedokteran Universitas Andalas yang telah menandatangani surat persetujuan pengisian kuesioner; mengikuti ujian Blok 1.1 MCE (Multiple Choice Examination). Kriteria eksklusi subjek: Mahasiswa Angkatan 2019 S1 Kedokteran FK Universitas Andalas yang tidak mengisi kuesioner dengan lengkap; indekos; sedang mengalami penyakit kronis atau penyakit yang berat, seperti kanker, hipertiroid; mempunyai riwayat gangguan dan pengobatan psikiatri.

Data diperoleh dengan cara pengisian kuesioner oleh responden. Kuesioner yang digunakan adalah Kriteria Rome IV untuk menentukan sindrom dispepsia, kuesioner DASS 21 yang berkaitan dengan faktor psikologis untuk menentukan depresi, ansietas, dan stres.

Data dianalisis secara statistik berdasarkan variabel yang dinilai menggunakan sistem komputerisasi yaitu analisis univariat dan bivariat. Analisis univariat dilakukan untuk melihat distribusi frekuensi dari masing-masing variabel independen dan variabel dependen. Analisis bivariat dilakukan untuk menganalisis hubungan antara variabel independen dan variabel dependen. Hubungan dua variabel tersebut dianalisis dengan menggunakan Fisher's Exact Test dan dikatakan bermakna bila $p<0.05$. Analisis perbedaan hasil sebelum dan sesudah ujian blok dianalisis dengan menggunakan Wilcoxon Match Pairs Test dan dikatakan bermakna bila $p<0.05$. Penelitian ini telah lulus kaji etik dengan nomor surat: 496/KEP/FK/2019. 
HASIL

Penelitian ini dilakukan terhadap 55 orang mahasiswa angkatan 2019 di Fakultas Kedokteran Universitas Andalas pada tanggal 11 - 30 September 2019. Selama periode tersebut jumlah responden yang memenuhi kriteria sebanyak 50 orang.

\section{Karakteristik Responden}

Tabel 1. Distribusi frekuensi karakteristik penderita sindrom dispepsia berdasarkan usia, jenis kelamin, tingkat pendidikan dan pekerjaan di Puskesmas Andalas

\begin{tabular}{lcc}
\hline Karakteristik & $\mathbf{f}$ & $\%$ \\
\hline Jenis Kelamin & & \\
Laki-laki & 16 & 32 \\
Perempuan & 34 & 68 \\
\hline Jumlah & 50 & 100 \\
\hline
\end{tabular}

Berdasarkan Tabel 1 dapat dilihat bahwa responden paling banyak adalah perempuan yaitu 34 orang, $68 \%$.

\section{Deskripsi Kejadian Depresi, Ansietas, dan Stres sebelum Ujian Blok}

Pada penelitian ini didapatkan tingkat depresi sebelum ujian blok yang paling banyak adalah depresi ringan. Penelitian ini mendapatkan ansietas sebelum ujian blok paling banyak adalah ansietas sedang. Pada penelitian ini didapatkan tingkat stres sebelum ujian blok yang paling banyak adalah stres ringan.

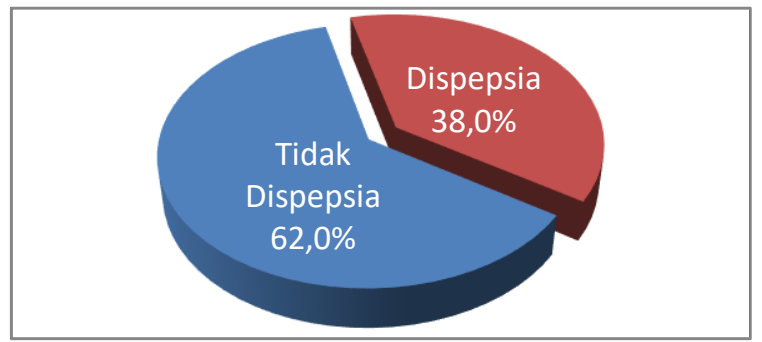

Gambar 1. Distribusi frekuensi kejadian sindrom dispepsia sebelum ujian blok

Pada penelitian ini kejadian sindrom dispepsia sebelum ujian blok adalah $38,0 \%$.
Deskripsi Kejadian Depresi, Ansietas, dan Stres sesudah Ujian Blok

Pada penelitian ini didapatkan tingkat depresi sesudah ujian blok yang paling banyak adalah depresi sedang. Pada penelitian ini didapatkan tingkat ansietas sesudah ujian blok yang paling banyak adalah anseitas sedang. Pada penelitian ini didapatkan tingkat stres sesudah ujian blok yang paling banyak adalah stres ringan dan sedang.

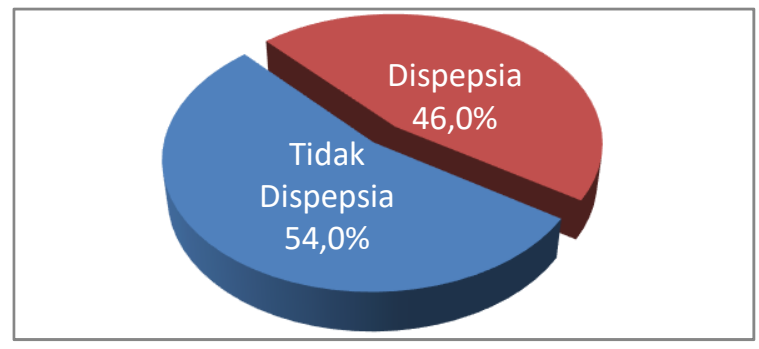

Gambar 2. Distribusi frekuensi kejadian sindrom dispepsia sesudah ujian blok

Pada penelitian ini kejadian sindrom dispepsia sebelum ujian blok adalah $46,0 \%$.

Tabulasi silang responden berdasarkan tingkat depresi, ansietas, dan stres sebelum dan sesudah ujian blok

Tabel 2. Tabulasi silang responden berdasarkan tingkat depresi, ansietas, dan stres sebelum dan sesudah ujian blok

\begin{tabular}{ccc}
\hline & Rank Rerata & * $\mathbf{p}$ \\
\hline Depresi sesudah ujian blok - Depresi & 5.50 & 0.004 \\
sebelum ujian blok & 8.38 & \\
\hline Ansietas sesudah ujian blok - & 17.43 & 0.004 \\
\hline Stres sesudah ujian blok - Stres & 11.00 & \\
sebelum ujian blok & 8.31 & 0.386 \\
\hline Dispepsia sesudah ujian blok - & 10.45 & \\
\hline Dispepsia sebelum ujian blok & 7.50 & 0.285 \\
\hline * Wilcoxon Match Pairs Test &
\end{tabular}

Berdasarkan Tabel 2 dapat dilihat bahwa hasil uji statistik menggunakan Wilcoxon Match Pairs Test untuk mengetahui perbedaan hasil pre dan post 
diperoleh perbedaan yang signifikan antara depresi sebelum dan sesudah ujian blok dengan nilai $p=0,004$ $(p<0,05)$. Ansietas sebelum dan sesudah ujian blok juga memiliki perbedaan yang signifikan dengan nilai $p=0,004(p<0,05)$. Stres dan Dispepsia tidak memiliki perbedaan yang signifikan sebelum dan sesudah ujian blok karena nilai $p>0,05$.

\section{Hubungan Depresi, Ansietas dan Stres dengan Kejadian Sindrom Dispepsia}

Tabel 3. Hubungan depresi, ansietas, dan stres dengan kejadian sindrom dispepsia

\begin{tabular}{|c|c|c|c|c|c|c|c|}
\hline & \multicolumn{4}{|c|}{$\begin{array}{c}\text { Dispepsia sesudah ujian } \\
\text { blok }\end{array}$} & \multirow{2}{*}{\multicolumn{2}{|c|}{ Total }} & \multirow{3}{*}{${ }^{*} p$} \\
\hline & \multicolumn{2}{|c|}{$\begin{array}{c}\text { Tidak } \\
\text { dispepsia }\end{array}$} & \multicolumn{2}{|c|}{ Dispepsia } & & & \\
\hline & $f$ & $\%$ & $f$ & $\%$ & $f$ & $\%$ & \\
\hline Tidak & 23 & 60,5 & 15 & 39,5 & 38 & 100 & \multirow{4}{*}{0,183} \\
\hline \multicolumn{7}{|l|}{ Depresi } & \\
\hline Depresi & 4 & 33,3 & 8 & 66,7 & 12 & 100 & \\
\hline \multirow[t]{3}{*}{ Total } & 27 & 54 & 23 & 46 & 50 & 100 & \\
\hline & \multicolumn{2}{|c|}{$\begin{array}{c}\text { Tidak } \\
\text { dispepsia }\end{array}$} & \multicolumn{2}{|c|}{ Dispepsia } & \multicolumn{2}{|c|}{ Total } & \\
\hline & $f$ & $\%$ & $f$ & $\%$ & $f$ & $\%$ & \\
\hline Tidak & 9 & 81,8 & 2 & 18,2 & 11 & 100 & \\
\hline Ansietas & & & & & & & \\
\hline Ansietas & 18 & 46,2 & 21 & 53,8 & 39 & 100 & 440 \\
\hline Total & 27 & 54 & 23 & 46 & 50 & 100 & \\
\hline
\end{tabular}

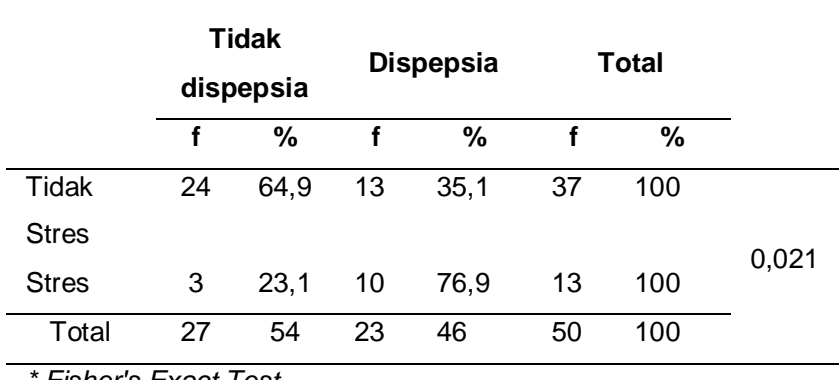

Pada tabel uji silang terdapat sel yang memiliki frekuensi harapan (expected count) kurang dari 5. Oleh karena itu, digunakan uji alternatif Chi-Square, yaitu Fisher's Exact Test.

Hasil uji statistik untuk depresi diperoleh nilai $p=0,183(p>0,05)$. Berdasarkan hasil tersebut dapat disimpulkan secara statistik bahwa tidak terdapat hubungan yang bermakna antara depresi dengan kejadian sindrom dispepsia. Hasil uji statistik untuk ansietas diperoleh nilai $p=0,046$ ( $p<0,05)$.
Berdasarkan hasil tersebut dapat disimpulkan secara statistik bahwa terdapat hubungan yang bermakna antara ansietas dengan kualitas hidup pada pasien sindrom dispepsia. Hasil uji statistik untuk stres diperoleh nilai $p=0,021(p<0,05)$. Berdasarkan hasil tersebut dapat disimpulkan secara statistik bahwa terdapat hubungan yang bermakna antara stres dengan kualitas hidup pada pasien sindrom dispepsia.

\section{PEMBAHASAN}

Mahasiswa S1 program studi profesi dokter Fakultas Kedokteran Universitas Andalas Angkatan 2019, dari penelitian yang telah disajikan pada lembar sebelumnya tentang deskripsi frekuensi tingkat depresi, ansietas, dan stres, sebelum ujian blok ternyata yang mengalami depresi sebanyak 10 (20,0\%), tingkat ansietas sedang yaitu 18 orang $(36,0 \%)$, stres berat 3 orang $(6,0 \%)$. Sedangkan pada kuesioner yang dijalankan setelah ujian blok di akhir minggu 1 pada blok 1.2 didapatkan prevalensi depresi, ansietas, dan stres mengalami peningkatan secara bermakna melalui Wilcoxon Match Pairs Test. Mahasiswa yang mengalami depresi sesudah ujian blok menjadi 16 orang $(32,0 \%)$, ansietas sebanyak 39 orang $(78,0 \%)$, dan stres berat sebanyak 5 orang $(10,0 \%)$. Hasil penelitian ini menunjukkan frekuensi kejadian depresi, ansietas, dan stres yang relatif tinggi pada mahasiswa tahun pertama FK Unand sebelum ujian blok dan memiliki perbedaan yang siginifikan sesudah ujian blok.

Menurut penelitian yang pada 104 mahasiswa reguler angkatan 2010 Fakultas IImu Keperawatan di Fakultas IImu Keperawatan Universitas Indonesia didapatkan yang normal yaitu 13 orang (12,5\%), tingkat stres ringan 32 orang (30,8\%), tingkat stres sedang 45 orang $(43,3 \%)$, tingkat stres berat 12 orang $(11,5 \%)$ dan tingkat stres paling berat 2 orang (1,9\%). ${ }^{17}$

Perbedaan berbagai hasil penelitian mungkin disebabkan beberapa faktor yang berpotensi menyebabkan depresi, ansietas dan stres pada mahasiswa seperti kegiatan akademik yaitu materi kuliah, perubahan dalam cara belajar, perubahan kurikulum, gagal dalam ujian dan ditambah tidak adanya remedial ujian blok. Hubungan fisik dan sosial juga menjadi faktor yang mempengaruhi stres seseorang, seperti perpindahan dari rumah pada mahasiswa yang bertempat tinggal indekos dan adanya 
fasilitas yang kurang memadai. Bervariasinya respon seseorang tergantung dari pengalaman belajar, kondisi medis, gender, dan kecenderungan genetis untuk mengalami tekanan atau masalah-masalah kesehatan. ${ }^{18}$ Menurut penelitian yang dilakukan pada mahasiswa kedokteran, sebanyak $84,0 \%$ stres disebabkan oleh ujian, 67,0\% karena alasan akademis, $31,0 \%$ karena masalah dalam keluarga, dan 31,0\% karena hubungan dengan sesama, sebanyak $26,0 \%$ stres terjadi karena rindu pada keluarga. ${ }^{19}$

Berdasarkan hasil uji normalitas data, bahwa data yang tidak terdistribusi normal, untuk mengetahui bagaimana perbedaan hasil pre dan post penelitian menggunakan nonparametric tests yaitu Wilcoxon Match Pairs Test.

Didapatkan hasil:

1. $p=0,004$ untuk depresi, artinya ada perbedaan antara tingkat depresi sebelum dan sesudah ujian blok;

2. $p=0,004$ untuk stres, artinya ada perbedaan antara tingkat ansietas sebelum dan sesudah ujian blok;

3. $p=0,386$ untuk stres, artinya tidak ada perbedaan antara tingkat stres sebelum dan sesudah ujian blok;

4. $p=0,285$ untuk dispepsia, artinya tidak ada perbedaan yang signifikan antara tingkat dispepsia sebelum dan sesudah ujian blok.

Berdasarkan hasil penelitian menggunakan Fisher's Exact Test menunjukkan hubungan yang signifikan antara ansietas dan stres dengan kejadian sindrom dispepsia dengan masing-masing nilai $p$ untuk stres $=0,021$ dan nilai $\mathrm{p}$ untuk ansietas $=0.046$ $(p<0,05)$. Tingkat depresi tidak ada hubungan yang signifikan dengan kejadian sondroma dispepsia karena nilai $p=0,183(p>0,05)$.

Respon fisiologis bisa diakibatkan oleh stres yang dialami seseorang dapat menimbulkan kecemasan yang erat kaitannya dengan pola hidup, gangguan kecemasan, diantaranya gangguan pencernaan. ${ }^{20}$ Berdasarkan penelitian pada mahasiswa Institut Pertanian Bogor terbukti bahwa tingkat stres berhubungan dengan timbulnya sindrom dispepsia yaitu semakin tinggi tingkat stres maka semakin sering muncul gejala sindrom dispepsia. ${ }^{21}$ Banyak faktor yang mempengaruhi terjadinya sindrom dispepsia, salah satunya adalah psikologis, seperti yang dibahas pada penelitian ini yaitu tingkat depresi, ansietas dan stres. Stres psikologis yang terjadi secara akut maupun kronik merupakan salah satu faktor pencetus terjadinya kekambuhan sindrom dispepsia. ${ }^{22}$

General Adaption Syndrome berdasarkan dengan teori Hans Selye terdiri dari 3 fase, yaitu fase reaksi alarm, fase pertahanan dimana saat tubuh berusaha menolak atau mengatasi stressor yang tidak dapat dihindari, fase kelelahan dimana tubuh mengalami stres yang berkelanjutan atau tubuh tidak mampu lagi beradaptasi pada stresor dan menjadi rentan terhadap masalah fisik dan pada akhirnya memunculkan penyakit. ${ }^{23}$ Berdasarkan data penelitian, didapatkan kejadian sindrom dispepsia lebih banyak terjadi pada mahasiswa angkatan 2019 sesudah ujian blok yang mengalami stres normal-ringan berat yaitu 13 orang dari 23 orang (56,52\%) dibandingkan stres sedang - sangat yaitu 10 orang dari 23 orang (43,48\%).

Output sensorik visceral dari organ seperti usus dan kandung kemih ke sistem saraf pusat terjadi terus menerus. Sinyal hasil dari rangsangan termasuk distensi organ berongga, peradangan, traksi pada mesenterium, dan iskemia. Fungsi fisiologis normal organ visceral, termasuk distensi dan kontraksi gastrointestinal, biasanya tidak menyakitkan. Namun, interpretasi subyektif dapat berubah karena peningkatan frekuensi atau amplitudo stimulus visceral, atau peningkatan sensitivitas terhadap stimulus yang biasanya menyakitkan (hyperalgesia) atau tidak menyakitkan (allodynia). Hipersensitivitas visceral dapat terjadi akibat perubahan pada sistem saraf perifer atau sentral dan memiliki etiologi yang kompleks tetapi semakin dipahami. ${ }^{24}$ Penelitian pada manusia dan hewan telah mengidentifikasi banyak faktor yang berkontribusi terhadap perubahan ini, dengan hipersensitivitas visceral sekarang dianggap sebagai salah satu mekanisme utama sindrom dispepsia. Menurut penelitian pada tahun 2011 terdapat peningkatan bermakna dari nilai kortisol serum pada pagi hari pada penderita sindrom dispepsia dengan gangguan psikosomatik terutama depresi berbanding dengan kelompok kontrol. ${ }^{25}$ 


\section{SIMPULAN}

Tingkat depresi dan tingkat ansietas sebelum dan sesudah ujian blok memiliki perbedaan yang signifikan.

Tingkat depresi tidak berhubungan dengan kejadian sindrom dispepsia sesudah ujian blok.

Tingkat ansietas berhubungan dengan kejadian sindrom dispepsia sesudah ujian blok.

Tingkat stres berhubungan dengan kejadian sindrom dispepsia sesudah ujian blok.

\section{SARAN}

Bagi instansi pendidikan, terutama Bagian Pendidikan Kedokteran/ Student Service Unit Fakultas Kedokteran Universitas Andalas diharapkan lebih memperhatikan kondisi psikologis mahasiswa S1 Kedokteran pada tahun pertama seperti mewujudkan konseling, atau edukasi serta evaluasi managemen stres sehingga lulusannya memiliki profesionalisme yang tinggi dengan aspek biologis, psikis, sosial, dan spiritual yang baik. Konseling yang diberikan oleh Bagian Pendidikan Kedokteran/ Student Service Unit diharapkan bisa memberikan penyelesaian masalah yang dialami mahasiswa sesuai dengan penyebabnya.

\section{UCAPAN TERIMA KASIH}

Terima kasih penulis sampaikan kepada semua instansi yang telah membantu penyelesaian penilitian ini terutama Dinas Kesehatan Kota Padang, Provinsi Sumatera Barat.

\section{DAFTAR PUSTAKA}

1. Djojoningrat $D$. dispepsia fungsional. Dalam: Aru W, Setiyohadi B, Alwi I, Simadibrata M, Setiati S, editor (penyunting). Buku ajar ilmu penyakit dalam Jilid II. Edisi ke-5. Jakarta: Interna Publishing; 2009.

2. Setiati S. Buku ajar ilmu penyakit dalam. Edisi ke-6. Jakarta: Interna Publishing FK UI; 2017.

3. Ford AC, Marwaha A, Sood R, Moayyedi PJG. Global prevalence of, and risk factors for, uninvestigated dyspepsia: a meta-analysis. 2015;64(7):1049-57.

4. Kementerian Kesehatan RI. Profil Kesehatan Indonesia 2010. Jakarta: Kementerian Kesehatan RI; 2011.
5. Dinas Kesehatan Kota Padang. Profil kesehatan kota Padang. 2017 (diunduh 18 April 2019). Tersedia dari: http://www.depkes.go.id

6. Muya $Y$, Murni AW, Herman RB. Karakteristik Penderita dispepsia fungsional yang mengalami kekambuhan di bagian ilmu penyakit dalam RSUP Dr. M. Djamil Padang, Sumatera Barat tahun 2011. Jurnal Kesehatan Andalas. 2015;4(2):490-5.

7. Susanti A. Faktor risiko dispepsia pada mahasiswa Institut Pertanian Bogor. Bogor: Departemen Gizi Masyarakat, Fakultas Ekologi Manusia, Institut Pertanian Bogor; 2011.

8. Hemriyantton $\mathrm{B}$, Arifin $\mathrm{H}$, Murni AW. Hubungan depresi terhadap tingkat kepatuhan dan kualitas hidup pasien sindrom dispepsia di RSUP Dr. M. Djamil Padang. Jurnal Sains Farmasi Klinis. 2017; 3(2):141-5.

9. Abdulghani HM, AlKanhal AA, Mahmoud ES, Ponnamperuma GG, Alfaris EA. Stress and its effects on medical students: a cross-sectional study at a college of medicine in Saudi Arabia. $\mathrm{J}$ Health Popul Nutr. 2011;29(5):516-22.

10. Gentile JP, Roman B. Medical student mental health services: psychiatrists treating medical students. Psychiatry. 2009;6(5):38.

11. Mudjaddid E. Pemahaman dan penanganan psikosomatik gangguan ansietas dan depresi di bidang ilmu penyakit dalam. Dalam: Sudoyo AW, Setyohadi B, Alwi I, Simadibrata M, Setiadi S, editor (penyunting). Buku Ajar IImu Penyakit Dalam Jilid II Edisi ke-4. Jakarta: Departemen IImu Penyakit Dalam FKUI; 2007.

12. Ariyani MD. Perbedaan tingkat stres mahasiswa kedokteran pada tahun pertama dan tahun ketiga di Universitas Muhammadiyah Malang. 2011 (diunduh Juni 2019). Tersedia dari: http://eprints.umm. ac.id/23248

13. Maulana ZF, Soleha TU, Saftarina F, Siagian. Perbedaan tingkat stres antara mahasiswa tahun pertama dan tahun kedua di Fakultas Kedokteran Universitas Lampung. Jurnal Majority. 2014;3(4):162.

14. Askandar NW. Analisis kecemasan mahasiswa kedokteran saat menghadapi objective structured clinical examination (OSCE). 2019 (diunduh 4 
Agustus 2019). Tersedia dari:

DOl:10.31227/osf.io/dcy.pf

15. Gazali MA. Hubungan tingkat stres dengan kejadian sindrom dispepsia pada mahasiswa fakultas kedokteran Universitas Andalas. 2018 (diunduh 10 April 2019). Tersedia dari: http://scholar.unand. ac.id/34930

16. Apriady T, Yanis A, Yulistini Y. Prevalensi ansietas menjelang ujian tulis pada mahasiswa kedokteran $\mathrm{fk}$ unand tahap akademik. Jurnal Kesehatan Andalas. 2016;5(3):666-9.

17. Haedhori. Hubungan penerapan pembelajaran model student centered learning (SCL) dengan tingkat stres mahasiswa keperawatan di Stikes Jenderal Achmad Yani Yogyakarta. 2017 (diunduh 4 Juli 2019). Tersedia dari: http://repository.unjaya. ac.id/2226

18. Wade C, Tavris, C. Psikologi. Edisi ke-9. Diterjemahkan oleh Juwono. Jakarta: Erlangga; 2007.

19. Fasoro AA, Oluwadare T, Ojo TF, Oni IO. Perceived stress and stressors among first-year undergraduate students at a private medical school in Nigeria. Journal of Taibah University Medical Sciences. 2019;14: 425-30.
20. Widyasari I. Hubungan antara kecemasan dan tipe kepribadian introvet dengan fungsional. 2011 (diunduh 4 Juli 2019). Tersedia dari: http://eprints. ums.ac.id/15978

21. Susanti A, Briawan D, Uripi V. Faktor risiko dispepsia pada mahasiswa Institut Pertanian Bogor (IPB). 2011;2(1):80-91.

22. Arrasyid C. Tingkat Keparahan Depresi pada Dispepsia Fungsional Dibandingkan pada Dispepsia Organik. Sub Divisi Bagian Penyakit Dalam Universitas Sumatera Utara [internet]. 2019 (diunduh 6 Juli 2019). Tersedia dari: http://repositori.usu.ac.id/bitstream/handle/1234567 8/16896/097101020.pdf

23. Noorhana. Buku Ajar Psikiatri: faktor psikologik yang mempengaruhi kondisi medis gangguan psikosomatik. Jakarta: Badan Penerbit FKUI; 2010.

24.Rosen JM. Visceral hypersensitivity and Electromechanical Dysfunction as Therapeutic Targets in Pediatric Functional Dyspepsia. World Journal of Gastrointestinal Pharmacology and Therapeutics. 2014;5(3):122.

25. Murni AW. Plasma cortisol levels in dyspepsia with psychosomatic patients. 2011 (diunduh 7 Juli 2019). Tersedia dari: http://repository.unand.ac.id/18327 